\title{
RESPIRATION AND TRANSPIRATION CHARACTERISTICS OF SELECTED FRESH FRUITS AND VEGETABLES.
}

\author{
K. TANO ${ }^{1}$, A. KAMENAN ${ }^{1}$ AND J. ARUL ${ }^{2}$ \\ 1UFR des «Sciences et Technologie des Aliments» Université d'Abobo - Adjamé, \\ 02 BP 801 Abidjan 02, Abidjan, Côte d'Ivoire. E-mail : pasqual_kab@hotmail.com \\ ${ }^{2}$ Department of Food Science and Nutrition and Horticulture Research Center. \\ Laval University Sainte-Foy, Quebec, Canada G1K 7P4
}

\begin{abstract}
Respiration and transpiration characteristics of mushrooms, strawberries, broccoli and tomatoes were determined under different temperature, atmospheric and humidity conditions in order to get information for modified humidity atmosphere conception. The respiration rate was determined using a static method (scanning method). The transpiration rate was measured using a new method at different relative humidity levels. The respiration rates of all the produce under optimal atmospheres were $40-60 \%$ lower than in air. The respiration quotients $(R Q)$ in both air and optimal atmospheres for all produce were lower than 1.0, but were higher in optimal atmospheres. The $Q_{10}$ values for respiration varied from 2.1 to 3.3 . It was shown that the transpiration rate was the sum of inherent, heat-transfer-induced and mass-transfer-induced transpiration. At low relative humidities in the surrounding atmosphere, mass-transfer-induced transpiration was the dominant mechanism for all produce. The better understanding of the respiration and transpiration behavior of produce under different conditions of temperature, atmosphere and humidity obtained in this study will lead to improve storage and modified atmosphere.
\end{abstract}

Key words : packaging, respiration, transpiration, temperature, relative humidity.

\section{RESUME}

LES CARACTERISTIQUES DE LA RESPIRATION ET DE LA TRANSPIRATION DES FRUITS ET LEGUMES FRAIS

La respiration et la transpiration du champignon, de la fraise, du brocoli et de la tomate ont été déterminées sous différentes conditions environnementales (température, atmosphère et humidité relative) dans le but d'obtenir des informations indispensables à la conception des emballages sous atmosphère modifiée. Les résultats montrent que la respiration des différents produits a été réduite de 40 à $60 \%$ par rapport à la respiration initiale dans l'air. Le quotient respiratoire $(R Q)$ pour tous les produits étudiés et sous les deux conditions d'entreposage est inférieur à 1. Cependant, sa valeur dans les conditions contrôlées est supérieure à celle obtenue dans l'air. La valeur du $Q_{10}$ pour l'intervalle de température étudiée varie de 2,1 à 3,3. Il a été montré que le taux de transpiration est la somme de la transpiration inhérente, de la transpiration due au transfert de masse et de celle due au transfert de chaleur. La parfaite connaissance de la respiration et de la transpiration sous différents facteurs environnementaux permettra de maîtriser la conception des emballages sous atmosphère modifiée et l'entreposage des fruits et légumes frais.

Mots clés : emballage, respiration, transpiration, température, humidité relative.

\section{INTRODUCTION}

Fruits and vegetables are living tissues, which continue to respire even after harvest. Control of respiratory metabolism is the basis of all storage techniques for fruits and vegetables. By decreasing respiration rate, the quality of fruits and vegetables can be maintained for a longer time, thus increasing product shelf life. High respiration rates increase tissue aging and decrease the ability of the product to repel microbial attack. Shelf life is inversely proportional to the respiration rate of fruits and vegetables. Several factors influence respiration rate. The most important of these being 
temperature (Murr and Morris, 1975a ; Kader et al., 1989, Church and Parson,1995). In addition to temperature, the composition of the atmosphere surrounding the product also has an influence (Kader, 1986). Decreasing the oxygen concentration and increasing the carbon dioxide concentration decreases the respiration rate of most products (Murr and Morris, 1975b ; Nichols and Hammond, 1975). Bastrash et al., (1993) have shown that an atmosphere made up of $8 \% \mathrm{CO}_{2}$ and $3 \% \mathrm{O}_{2}$ prolongs the shelf-life of broccoli to seven weeks, delaying yellowing of the florets and reducing the number of infected sites. Burton et al., (1987) has found that $5 \%$ $\mathrm{O}_{2}$ is suitable for slowing the development of fresh mushrooms. Sveine et al., (1967) made similar observations and also showed that $5 \% \mathrm{CO}_{2}$ delays the opening of mushroom caps. Similarly, an atmosphere composed of 2.5 to $5 \% \mathrm{O}_{2}$ improves the storage of tomatoes, but the $\mathrm{CO}_{2}$ concentration must not exceed $5 \%$ (Bhowmik and Pan, 1992 ; Lockhart and Eaves, 1967 ; Salunke and $\mathrm{Wu}, 1973)$. The respiration of strawberries is strongly decreased when stored under an atmosphere of decreased oxygen content $\left(5-6 \% \mathrm{O}_{2}\right)$ but rich in $\mathrm{CO}_{2}$ (15 to $20 \%$ $\mathrm{CO}_{2}$ ) (Doyon, 1989 ; Harris and Harvey, 1973 ; Smith, 1992).

Transpiration may also affect post harvest physiology and hence the quality of fruits and vegetables. This factor depends on the vapour pressure deficit between the product and its surrounding atmosphere and on product characteristics such as the surface-volume ratio, structure and composition of the product (Grierson and Wardowski, 1978 ; Ben-Yehoshua, 1985 ; Patel et al., 1988 ; Xu et al., 1995 ; BenYehoshua, 1987). The design of modified atmosphere packaging requires precise knowledge of the respiration and transpiration rates of the product being stored as well as the response of these two physiological parameters to environmental factors, namely temperature, atmospheric composition and relative humidity.

The purpose of this study is to determine the respiration rate of four fruits and vegetables as a function of storage atmosphere and temperature using a static method (scanning method) and also to establish a simple and precise method for measuring transpiration of the four products as a function of relative humidity.

\section{MATERIALS AND METHODS}

All the experiments were carried out at the laboratory of Food Science and Nutrition department, Laval University, Quebec, Canada, during 1999 and 2000.

\section{FRUITS AND VEGETABLES}

In this study, the four fruits and vegetables studied (mushrooms, Cv. U3 sylvan 381 ; tomatoes, Cv. Trust ; broccoli, Cv. Acadi ; strawberries, Cv. Kent) were grown in the Quebec City region. All products were pre-cooled for 24 hours on reception, after sorting according to size, state of maturity and state of ripening.

\section{PACKAGES}

Two types of containers were used for the determination of respiration. Mushrooms and strawberries were packaged in 4.0 L Plexiglas containers. Broccoli and tomatoes were packaged in $6.3 \mathrm{~L}$ Plexiglas containers.

\section{STORAGE CONDITIONS}

In the first experiment, respiration as a function of storage time was measured at the optimal temperature for each product $\left(4^{\circ} \mathrm{C}\right.$ for mushroom and strawberry, $3^{\circ} \mathrm{C}$ for broccoli and $13^{\circ} \mathrm{C}$ for tomato) in air or in the optimal atmosphere. The optimal atmospheres were $5 \% \mathrm{O}_{2}-10 \% \mathrm{CO}_{2}$ for mushroom and tomato, $6 \% \mathrm{O}_{2}-15 \% \mathrm{CO}_{2}$ for strawberry and $3 \% \mathrm{O}_{2}-8 \% \mathrm{CO}_{2}$ for broccoli.

In the second experiment, respiration as a function of tree temperature was measured in an atmosphere of optimal composition and in air.

In the third experiment, transpiration was measured at five levels of relative humidity $(65 \%$, $75 \%, 87 \%, 96 \%$ et $100 \%$ ) at the optimal storage temperature of each product.

\section{USE OF SATURATED SALT SOLUTIONS}

To maintain constant relative humidity inside each package, standard saturated salt solutions were prepared. The following salts were employed as saturated solutions to give water activity at 
the each experiment temperature shown in parentheses: $\mathrm{NaNO}_{2}(0.65), \mathrm{NaCl}(0.75), \mathrm{KCl}$ (0.87), $\mathrm{KNO}_{3}(0.96)$. A humidity of $100 \%$ was obtained with distilled water.

\section{RESPIRATION MEASUREMENT METHOD}

Respiration was measured as a function of time at three temperatures by a so-called static method under controlled atmosphere. Sealed packages containing product (mushroom : $750 \mathrm{~g}$; strawberry : $1000 \mathrm{~g}$; tomatoes : $2500 \mathrm{~g}$ and broccoli : $2800 \mathrm{~g}$ ) were vented and flushed with gas mixtures corresponding with the optimal atmospheric composition for each product. The flow rates were adjusted to levels appropriate for literature values for produce respiration rate (Kader et al., 1989 ; Exama et al., 1993) and kept constant throughout the experiment. To measure respiration, gas flow was interrupted and a $1 \mathrm{~cm}^{3}$ sample of gas was removed from the package using a polypropylene syringe. The sample was then analysed using a gas chromatograph equipped with a thermal conductivity detector. After one to two hours, the time required for $\mathrm{CO}_{2}$ to accumulate and for $\mathrm{O}_{2}$ to diminish, a second $1.0 \mathrm{~cm}^{3}$ sample was removed for analysis. Samples were taken three times per day throughout the three-day storage period. An airflushed package served as a control. The experiment was done in triplicate for all treatments. The results obtained in percentage of enriched $\mathrm{CO}_{2}$ and depleted $\mathrm{O}_{2}$ were transformed in $\mathrm{ml} / \mathrm{kg} / \mathrm{h}$ by using the package void volume of each product.

\section{Estimation of respiratory parameters}

Activation energy, pre-exponential factor, temperature coefficient $\left(Q_{10}\right)$ and respiratory quotient $(R Q)$ were calculated using the measurements of respiration at the different temperatures and the Arrhenius equation (Exama et al., 1993).

\section{Monitoring transpiration as a function of relative humidity}

Containers were flushed with pure air dehumidified by passing through a drying tube containing a desiccant, through a second tube packed with hydrophilic paper soaked with saturated salt solution, through an Erlenmeyer flask containing the same solution, through an empty flask serving as a trap for droplets, through a four-way valve used as a distributor to the packages and finally through flowmeters to control air flow rate. The air flow rate was adjusted to the respiration rate of each product (9.75 ml/h for mushroom, $30 \mathrm{ml} / \mathrm{h}$ for broccoli, $10 \mathrm{ml} / \mathrm{h}$ for strawberry and $12.5 \mathrm{ml} / \mathrm{h}$ for tomato. Packages were equipped with type $\mathrm{T}$ thermocouple probes and hygrometers connected to a datalogger and monitored for nine days. Airflow was interrupted every three days to obtain product weight by weighing the contents of the package. Transpiration rates were estimated using the weight losses over the threeday intervals. Measurements were done in triplicata at each relative humidity.

\section{Statistical analysis}

All the experiments were repeated. Since, there was no significant difference between the 2 experiments, the results were pooled and averaged. Data on respiration rate and transpiration rate were submitted to an analysis of variance, followed by Neuwman - Keul's multiple comparison test (alpha $=0.05$ ).

\section{RESULTS}

\section{RESPIRATIONAND RESPIRATORY QUOTIENT AS AFUNCTION OF TIME}

\section{Mushrooms}

Figures $1 \mathrm{~A}, 1 \mathrm{~B}$ and $1 \mathrm{C}$ represent $\mathrm{CO}_{2}$ production, $\mathrm{O}_{2}$ consumption and the respiratory quotient $(R Q)$ in the optimal atmosphere and in air respectively for mushrooms. In both atmospheres, respiration peaked over time, with level plateaus on either side of the peak, albeit at a higher level after the peak. In the optimal atmosphere, the respiratory quotient of mushrooms varied from 0.87 to 0.99 after 16 hours (Figure 1C) and remaining constant for the of storage time (12 days). The RQ also rose in the presence of air but remained lower than in the optimal atmosphere throughout the storage period. Respiration rate was significantly higher in air than in the optimal atmosphere. 


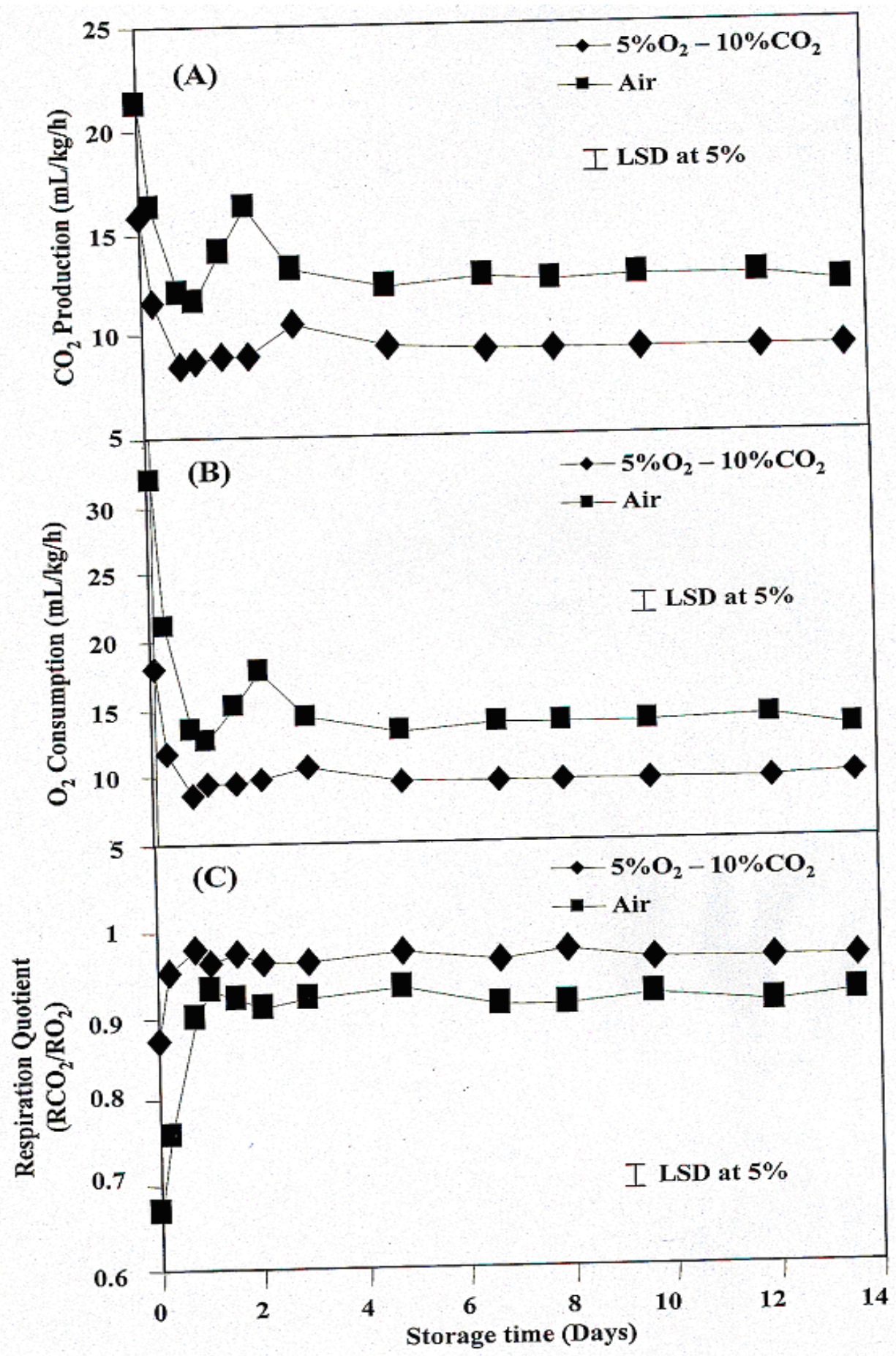

Figure 1 : Respiration rate and respiration quotient (RQ) of mushrooms stored in controlled atmosphere $\left(5 \% \mathrm{O}_{2}-10 \% \mathrm{CO}_{2}\right)$ and in air conditions at $4^{\circ} \mathrm{C}$.

Taux de respiration et quotient respiratoire du champignon entreposé sous atmosphère contrôlée $\left(5 \% \mathrm{O}_{2}-10 \% \mathrm{CO}_{2}\right)$ et dans l'air à la température de $4^{\circ} \mathrm{C}$. 


\section{Strawberries}

Production of $\mathrm{CO}_{2}$ and consumption of $\mathrm{O}_{2}$ at the beginning of storage were $15.6 \mathrm{ml} / \mathrm{kg} / \mathrm{hr}$ and $17.9 \mathrm{ml} / \mathrm{kg} / \mathrm{hr}$ respectively in the optimal atmosphere and $16.6 \mathrm{~mL} / \mathrm{kg} / \mathrm{hr}$ and $21.0 \mathrm{~mL} / \mathrm{kg} / \mathrm{hr}$ for storage in air (Figures $2 \mathrm{~A}$ and 2B). Respiration subsequently decreased in both cases, but remained higher in the presence of air. The RQ in air varied from 0.79 to 0.92 and from 0.87 to 0.98 in the optimal atmosphere. After one day of storage in this atmosphere, $\mathrm{CO}_{2}$ production and $\mathrm{O}_{2}$ consumption stabilized at $4.0 \mathrm{ml} / \mathrm{kg} / \mathrm{hr}$ and $4.6 \mathrm{ml} / \mathrm{kg} / \mathrm{hr}$ respectively, while the corresponding figures for air were $9.0 \mathrm{ml} / \mathrm{kg} / \mathrm{hr}$ and $10.0 \mathrm{ml} / \mathrm{kg} / \mathrm{hr}$. Use of the optimal atmosphere allowed a $50 \%$ reduction in respiration compared to air.

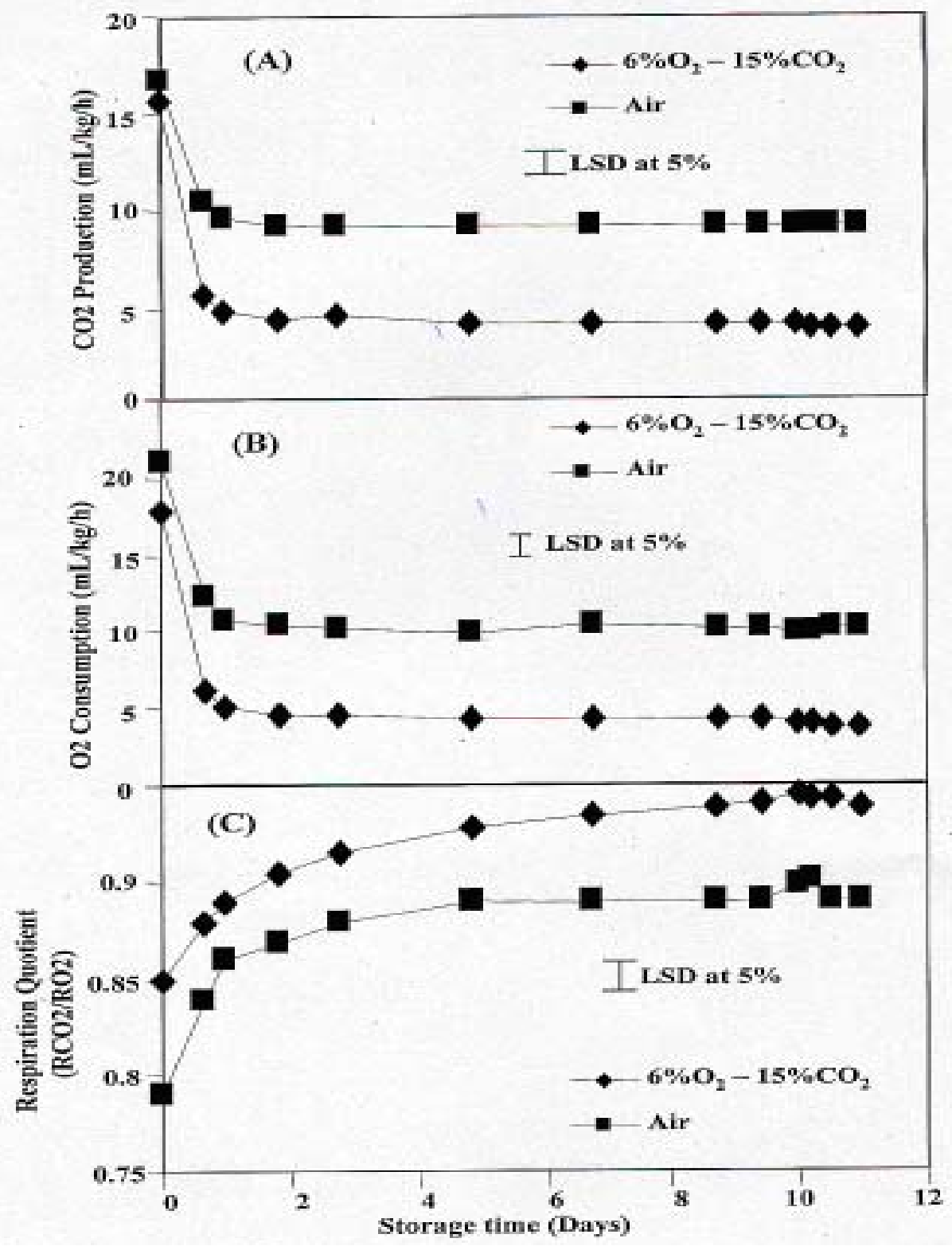

Figure 2 : Respiration rate and respiration quotient $(R Q)$ of strawberries stored in controlled atmosphere $\left(6 \% \mathrm{O}_{2}-15 \% \mathrm{CO}_{2}\right)$ and in air conditions at $4^{\circ} \mathrm{C}$.

Taux de respiration et quotient respiratoire de la fraise entreposée sous atmosphère contrôlée $\left(6 \% \mathrm{O}_{2}-15 \% \mathrm{CO}_{2}\right)$ et dans l'air à la température de $4^{\circ} \mathrm{C}$. 


\section{Broccoli}

Figure 3 represents respiration and respiratory quotient of broccoli stored in the two atmospheres. Both show three zones : a rapid decrease in respiration from days 0 to 2 , a more gradual decrease from days 2 to 10 and a stabilized state from day 10 through 35 . Under optimal atmosphere, $\mathrm{CO}_{2}$ production and $\mathrm{O}_{2}$ consumption passed from initial values of $33.4 \mathrm{ml} / \mathrm{kg} / \mathrm{hr}$ and $37.0 \mathrm{ml} / \mathrm{kg} / \mathrm{hr}$ respectively to $7.5 \mathrm{ml} / \mathrm{kg} / \mathrm{hr}$ and $7.7 \mathrm{ml} / \mathrm{kg} / \mathrm{hr}$ at equilibrium
(Figures 3A and 3B). In the presence of air, the corresponding figures are from $27.9 \mathrm{ml} / \mathrm{kg} / \mathrm{hr}$ and $37.0 \mathrm{ml} / \mathrm{kg} / \mathrm{hr}$ to $9.5 \mathrm{ml} / \mathrm{kg} / \mathrm{hr}$ and $10.8 \mathrm{ml} / \mathrm{kg} / \mathrm{hr}$. Respiration in the optimal atmosphere was thus $30 \%$ lower than in air. But compared to the initial values, respiration decreased by $70 \%$ in both cases at the stabilized state. The respiratory quotient in the optimal atmosphere was always higher than that in air, although both rose from their initial values and stabilized after 8 to 10 days.

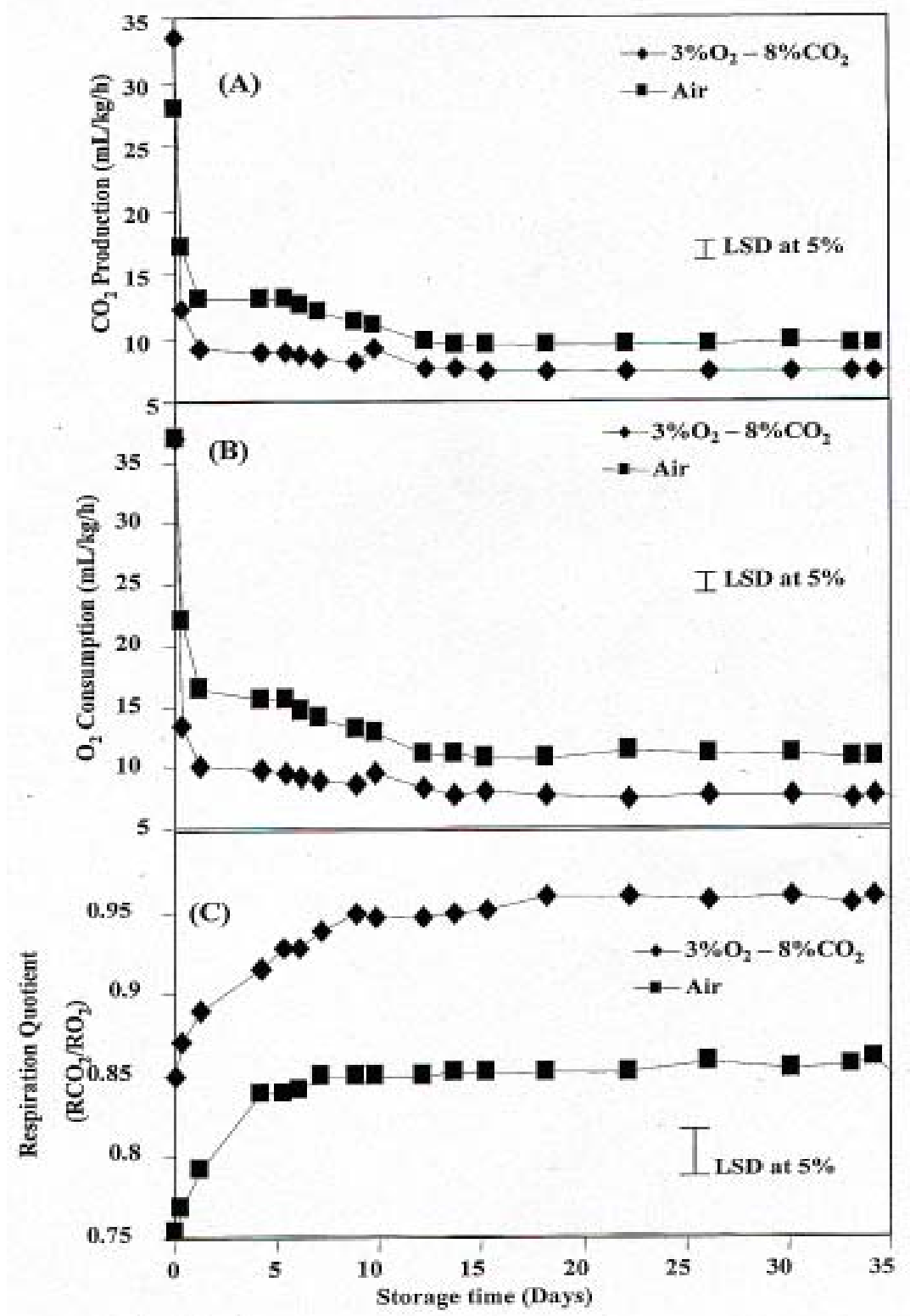

Figure 3 : Respiration rate and respiration quotient (RQ) of broccoli stored in controlled atmosphere $\left(3 \% \mathrm{O}_{2}-8 \% \mathrm{CO}_{2}\right)$ and in air conditions at $3^{\circ} \mathrm{C}$.

Taux de respiration et quotient respiratoire du broccoli entreposé sous atmosphère contrôlée $\left(3 \% \mathrm{O}_{2}-8 \% \mathrm{CO}_{2}\right)$ et dans l'air à la température de $3^{\circ} \mathrm{C}$. 


\section{Tomatoes}

Figure 4 shows respiration and respiratory coefficients for tomatoes. In both atmospheres, the respiration curve exhibits four zones. There is an initial drop followed by a first plateau lasting 7 days in air but extending over 20 days in the optimal atmosphere. Then there is a rapid increase for three to five days followed by a decrease to another plateau. Again, respiration was lower in the optimal condition, by about $50 \%$ in this case, and a decrease of nearly $70 \%$ from the initial value was seen. Respiratory quotients differed significantly $\left({ }^{* *} \mathrm{P}<0.05\right)$, increasing to 0.95 (air) and 1.05 (optimal atmosphere).

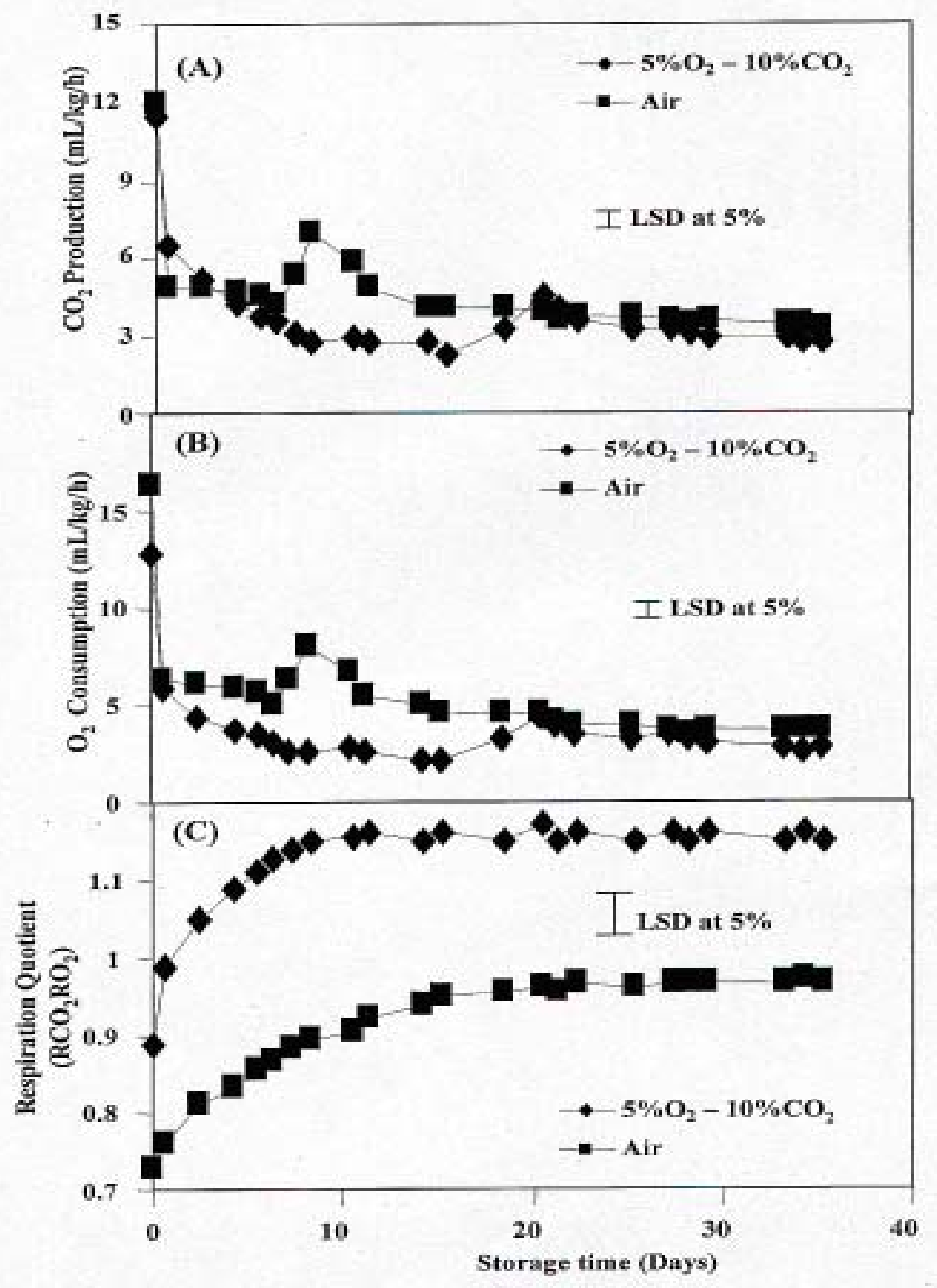

Figure 4 : Respiration rate and respiration quotient $(R Q)$ of tomatoes stored in controlled atmosphere $\left(5 \% \mathrm{O}_{2}-10 \% \mathrm{CO}_{2}\right)$ and in air conditions at $13^{\circ} \mathrm{C}$.

Taux de respiration et quotient respiratoire de la tomate entreposée sous atmosphère contrôlée $\left(5 \% \mathrm{O}_{2}-10 \% \mathrm{CO}_{2}\right)$ et dans l'air à la température de $13^{\circ} \mathrm{C}$. 


\section{EFFECT OF TEMPERATURE ON RESPIRATION}

Table 1 shows the effect of temperature on respiration for the four fruits and vegetables. In general, respiration increases with temperature. For mushrooms stored under $5 \% \mathrm{O}_{2}$ and $10 \%$ $\mathrm{CO}_{2}, \mathrm{CO}_{2}$ production rates at $4^{\circ} \mathrm{C}, 14^{\circ} \mathrm{C}$ and $24^{\circ} \mathrm{C}$ were $9.9 \mathrm{ml} / \mathrm{kg} / \mathrm{hr}, 28.8 \mathrm{ml} / \mathrm{kg} / \mathrm{hr}$ and $83.3 \mathrm{ml} / \mathrm{kg} / \mathrm{hr}$ respectively. Consumption of $\mathrm{O}_{2}$ at these temperatures was $10.7 \mathrm{ml} / \mathrm{kg} / \mathrm{hr}$, $30.7 \mathrm{ml} / \mathrm{kg} / \mathrm{hr}$ and $92.6 \mathrm{ml} / \mathrm{kg} / \mathrm{hr}$ respectively.
Variations were similar in both atmospheres, although respiration was always higher in air. The respiratory quotient for mushrooms decreased with increasing temperature in both atmospheres but increased for the other three products. Regardless of temperature, respiration rates were highest for mushrooms, followed by broccoli, strawberries and finally tomatoes. For all products and temperatures, the $R Q$ was close to unity in the optimal atmosphere and always higher than in air.

Table 1 : Respiration rate and respiration quotient (RQ) of mushrooms, strawberries, broccoli and tomatoes under different temperatures and atmospheres conditions.

Taux de respiration et quotient respiratoire (RQ) du champignon, de la fraise, du brocoli et da la tomate sous différentes conditions de température et d'atmosphère.

\begin{tabular}{|c|c|c|c|c|c|}
\hline \multirow[b]{2}{*}{ Product } & \multirow{2}{*}{$\begin{array}{c}\text { Atmosphere } \\
\left(\% \mathrm{O}_{2}-\% \mathrm{CO}_{2}\right)\end{array}$} & \multirow{2}{*}{$\begin{array}{c}\mathrm{T} \\
\left({ }^{\circ} \mathrm{C}\right)\end{array}$} & $\mathrm{RCO}_{2}$ & $\mathrm{RO}_{2}$ & \multirow{2}{*}{$\begin{array}{c}\mathrm{RQ} \\
\left(\mathrm{RCO}_{2} / \mathrm{RO}_{2)}\right.\end{array}$} \\
\hline & & & \multicolumn{2}{|c|}{$\mathrm{mL} \cdot \mathrm{kg}^{-1} \cdot \mathrm{h}^{-1}$} & \\
\hline \multirow{6}{*}{ Mushroom } & \multirow{3}{*}{$5-10$} & 4 & $9.94 \pm 0.45$ & $10.65 \pm 0.39$ & 0.94 \\
\hline & & 14 & $28.83 \pm 0.49$ & $30.67 \pm 0.61$ & 0.94 \\
\hline & & 24 & $83.31 \pm 0.88$ & $92.57 \pm 0.97$ & 0.90 \\
\hline & \multirow{3}{*}{ Air } & 4 & $12.94 \pm 0.44$ & $16.81 \pm 0.79$ & 0.77 \\
\hline & & 14 & $39.41 \pm 0.51$ & $53.26 \pm 1.21$ & 0.74 \\
\hline & & 24 & $117.95 \pm 0.32$ & $159.14 \pm 2.12$ & 0.73 \\
\hline \multirow{6}{*}{ Strawberry } & \multirow{3}{*}{$6-15$} & 4 & $5.33 \pm 0.19$ & $5.99 \pm 0.44$ & 0.89 \\
\hline & & 14 & $13.79 \pm 0.21$ & $13.70 \pm 0.27$ & 1.00 \\
\hline & & 20 & $23.31 \pm 0.33$ & $22.21 \pm 0.69$ & 1.01 \\
\hline & \multirow{4}{*}{ Air } & 4 & $9.62 \pm 0.70$ & $11.93 \pm 0.86$ & 0.81 \\
\hline & & 14 & $26.43 \pm 0.39$ & $29.72 \pm 0.62$ & 0.88 \\
\hline & & 20 & $43.98 \pm 0.96$ & $46.02 \pm 1.17$ & 0.96 \\
\hline \multirow{6}{*}{ Broccoli } & & 3 & $8.50 \pm 0.48$ & $9.00 \pm 0.17$ & 0.95 \\
\hline & \multirow[t]{3}{*}{$3-8$} & 13 & $19.90 \pm 0.17$ & $20.00 \pm 0.32$ & 0.95 \\
\hline & & 23 & $40.03 \pm 0.85$ & $45.10 \pm 0.69$ & 0.89 \\
\hline & & 3 & $10.33 \pm 0.66$ & $14.70 \pm 0.43$ & 0.70 \\
\hline & \multirow[t]{3}{*}{ Air } & 13 & $34.18 \pm 0.76$ & $44.53 \pm 0.87$ & 0.77 \\
\hline & & 23 & $102.98 \pm 1.98$ & $122.22 \pm 1.55$ & 0.84 \\
\hline \multirow{6}{*}{ Tomato } & & 13 & $1.60 \pm 0.09$ & $1.52 \pm 0.08$ & 1.05 \\
\hline & \multirow[t]{2}{*}{$5-10$} & 18 & $2.41 \pm 0.17$ & $2.36 \pm 0.10$ & 1.02 \\
\hline & & 23 & $3.34 \pm 0.13$ & $3.06 \pm 0.11$ & 1.09 \\
\hline & \multirow{3}{*}{ Air } & 13 & $5.01 \pm 0.21$ & $5.35 \pm 0.19$ & 0.94 \\
\hline & & 18 & $8.41 \pm 0.27$ & $8.66 \pm 0.23$ & 0.97 \\
\hline & & 23 & $13.41 \pm 0.31$ & $12.97 \pm 0.15$ & 1.03 \\
\hline
\end{tabular}

\section{ARRHENIUS EQUATION PARAMETERS AND $Q_{10}$ VALUES}

Using the Arrhenius equation and the respiration data at the different temperatures, preexponential respiration and activation energies were calculated for each product (Table 2 ). The $\mathrm{Q}_{10}$ values for $\mathrm{O}_{2}$ consumption and $\mathrm{CO}_{2}$ production are also given for the optimal atmosphere and for air. For all products studied, pre-exponential respiration in air was greater than in the optimal atmosphere. The activation energy for mushrooms was about $75 \mathrm{~kJ}^{\mathrm{mol}}{ }^{-1}$. The $\mathrm{Q}_{10}$ for $\mathrm{CO}_{2}$ production in the optimal atmosphere was 2.9 and 3.10 in air. For strawberries, $Q_{10}$ values of 2.4 (for $\mathrm{CO}_{2}$ production) and 2.2 (for $\mathrm{O}_{2}$ consumption) were obtained in the optimal atmosphere while values of 2.8 and 2.5 were obtained in air. For all products, $Q_{10}$ values were significantly lower in the modified atmosphere than in air, as were activation energies $\left({ }^{* *} \mathrm{P}<0.05\right)$. 
Table 2 : Activation energy $(\mathrm{Er})$ and temperature coefficient $\left(\mathrm{Q}_{10}\right)$ of mushrooms, strawberries, broccoli and tomatoes under different temperatures and atmospheres conditions.

Energie d'activation (Er) et coefficient de température $\left(Q_{10}\right)$ du champignon, de la fraise, du brocoli et de la tomate en atmosphère contrôlée et dans l'air.

\begin{tabular}{lccccc}
\hline & Atmosphere & \multicolumn{2}{c}{$\mathrm{E}_{\mathrm{R}}\left(\mathrm{kJ} \cdot \mathrm{mol}^{-1}\right)$} & \multicolumn{2}{c}{$\mathrm{Q}_{10}$} \\
\cline { 3 - 6 } Product & $\% \mathrm{O}_{2}-\% \mathrm{CO}_{2}$ & $\mathrm{CO}_{2}$ & $\mathrm{O}_{2}$ & $\mathrm{CO}_{2}$ & $\mathrm{O}_{2}$ \\
\hline \multirow{2}{*}{ Mushroom } & $5-10$ & 72.73 & 73.96 & 2.90 & 2.89 \\
& Air & 75.61 & 76.92 & 3.10 & 3.12 \\
Strawberry & $6-15$ & 62.31 & 55.28 & 2.39 & 2.20 \\
& Air & 64.42 & 57.34 & 2.75 & 2.49 \\
Broccoli & $3-8$ & 57.37 & 54.75 & 2.18 & 2.25 \\
& Air & 78.15 & 71.98 & 3.30 & 3.02 \\
Tomato & $5-10$ & 51.84 & 49.35 & 2.10 & 2.01 \\
& Air & 69.44 & 62.42 & 2.67 & 2.42 \\
\hline
\end{tabular}

\section{TRANSPIRATION AS A FUNCTION OF RELATIVE HUMIDITY}

All produce examined experienced a significant rate of transpiration even at $100 \%$ relative
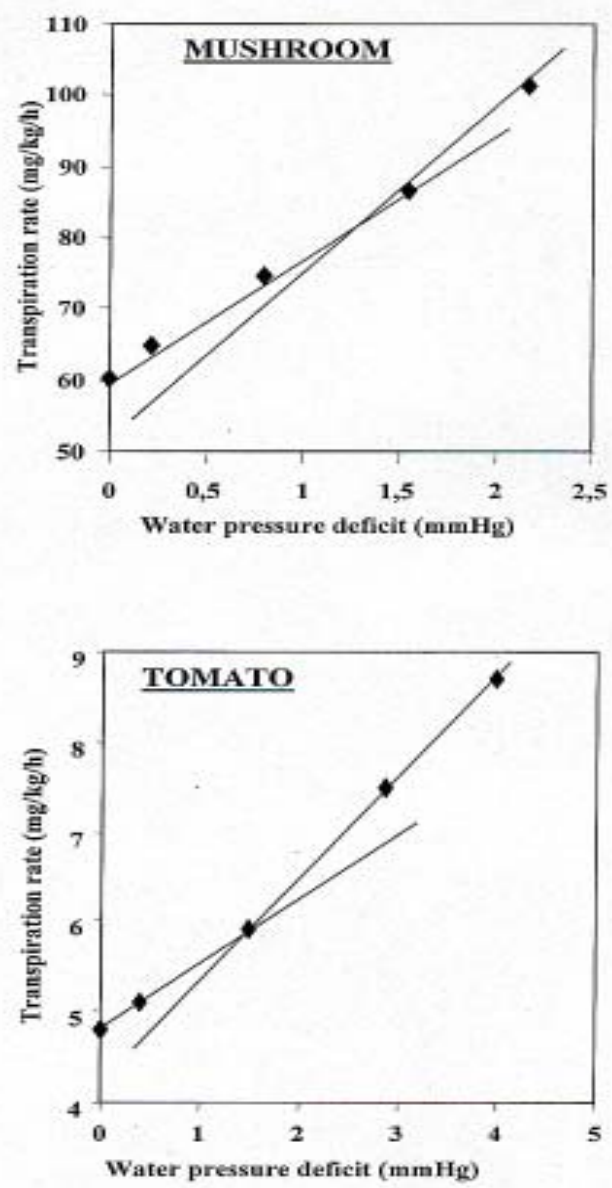

humidity (Figure 5). The transpiration rate also appeared to significantly increase for all products with decreasing humidity or with a difference between product and package atmosphere water vapour pressures.
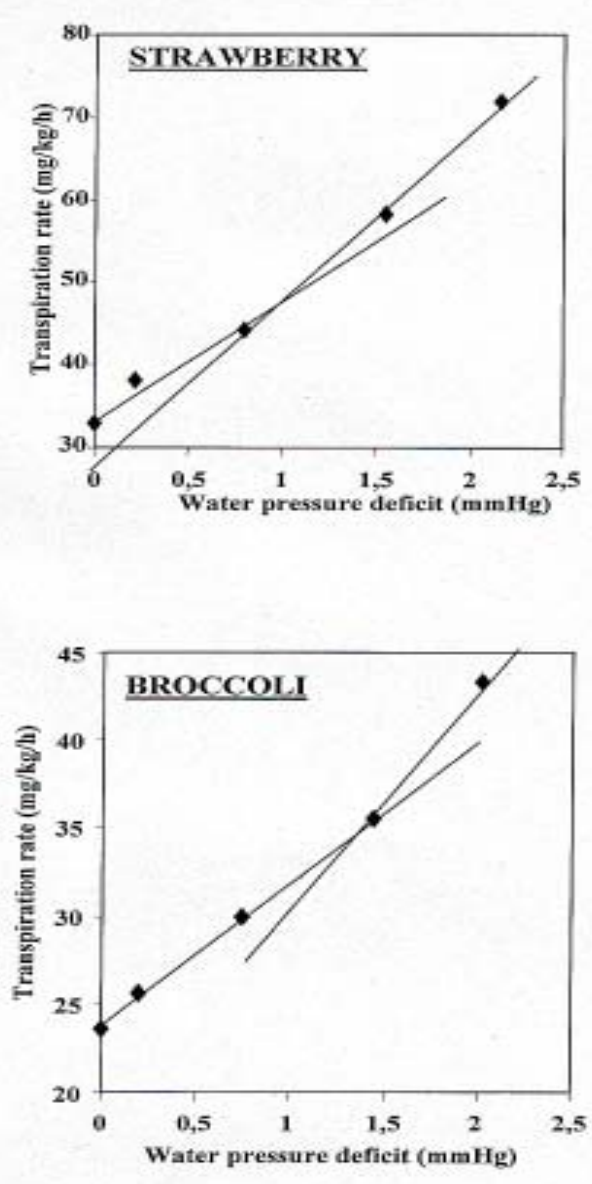

Figure 5 : Transpiration rate of mushrooms, strawberries, broccoli and tomatoes as function of the vapour pressure deficit.

Taux de transpiration du champignon, de la fraise, du brocoli et de la tomate en fonction du déficit de pression de vapeur. 
Mushrooms transpired at a rate of $60.1 \mathrm{mg} / \mathrm{kg} / \mathrm{hr}$ when the Differential Vapour Pressure (DVP) was zero $(\mathrm{RH}=100 \%)$. This rate rapidly increased to $101.3 \mathrm{mg} / \mathrm{kg} / \mathrm{hr}$ at a difference of $2.16 \mathrm{mmHg}$. For strawberries and broccoli, the zero differential transpiration rates were approximately half of that experienced by mushrooms. The zero differential rate for tomatoes was much smaller than was observed with the over produce $(4.8 \mathrm{mmHg})$. Transpiration rates approximately doubled for mushrooms, strawberries and broccoli when the water vapour pressure differential reached 2.16 mmHg. However, less dramatic transpiration rate increases were observed with tomatoes, with this produce the DVP had increased to $3.98 \mathrm{mmHg}$ before a double of transpiration rate was observed.

\section{DISCUSSION}

\section{EFFECT OF TEMPERATURE AND ATMOSPHERE ON RESPIRATION}

The respiration of fruits and vegetables depends on several factors including the nature of the atmosphere surrounding the product (Figures 1 through 4). Decreasing oxygen concentration and increasing carbon dioxide concentration significantly decreased respiration at the same temperature in all four products studied. The rapid decrease in respiration during the first 24 hours is probably due to the effect of temperature but also to the fact that respiration normally decreases after harvesting and moreso in unripe tissues than in ripe tissues (Kader, 1987). This decrease occurs as the limited substrate reserves for respiratory metabolism are depleted. Storage of tomatoes in the optimal atmosphere delayed the climacteric respiration phase (Figure 4A). Under these conditions, climacteric respiration began after three weeks of storage, while in air, the onset of this phase occurred at day 10 . These results are in agreement with those of Bhowmik and Pan (1992). In the case of mushrooms, the growth phase in the optimal atmosphere is delayed by two days beyond that for mushrooms stored in air (Bolhing and Hassen, 1980).

Generally, respiration decreases with tissue water content. Product composition determines what type of substrate is available for respiration and consequently the respiratory quotient (Kader, 1987). Under aerobic conditions and depending on the product, the respiratory quotient may vary between 0.7 and 1.3. The availability of oxygen around the product also affects the respiratory quotient of the product, however (Bhowmik and Pan, 1992 ; Murr and Morris, 1975a), as corroborated by the results of the present study. The respiratory quotient is always lower in air than in the optimal atmosphere. This difference may be attributable to the different oxygen concentrations (KatoNoguchi and Watada, 1996).

The effect of temperature on respiration in fresh fruits and vegetables is very significant (Kader, 1987 ; Phan, 1987 ; Cameron et al., 1994). A wide variety of enzymatic reactions are involved in respiration. The rate of all of these reactions increases exponentially with increasing temperature within the physiological temperature range (Exama et al., 1993). The exact manner by which respiration increases may be described mathematically as the temperature coefficient $\left(Q_{10}\right)$ or activation energy (Er). The $Q_{10}$ of the products studied varied between 2.1 and 3.3 depending on the atmosphere surrounding the product and on the range over which the temperature varied (Table 2). Produce like mushrooms with higher $Q_{10}$ values would be more affected by temperature fluctuations inside the package.

\section{EFFECT OF RELATIVE HUMIDITY ON TRANSPIRATION}

The method of transpiration measurement used in the present study has provided values close to previously reported values (Ben-yehoshua, 1987 ; Sastry et al., 1978 ; Robinson et al., 1975). Sastry et al., (1978) found that respiration rates of broccoli and tomatoes are respectively $31.2 \mathrm{mg} / \mathrm{kg} / \mathrm{h}$ and $4.2 \mathrm{mg} / \mathrm{kg} / \mathrm{h}$, when relative humidity varies between $45 \%$ and $75 \%$. However, our analysis method has the advantage that it can directly determine product transpiration in milligrams of water evaporated per kilogram of product whereas previously reported values are given as a percentage of product weight per unit of storage time and a specified interval of relative humidity. The latter method does not allow the determination of transpiration when the difference in vapour pressure between the product and the package atmosphere is zero.

To properly understand the various mechanisms underlying transpiration, we must start by examining respiration because the two phenomena are intimately linked. Respiration 
can be characterized by the following equation :

$$
\underset{2816 \mathrm{~kJ}}{\mathrm{C}_{6} \mathrm{H}_{12} \mathrm{O}_{6}}+6 \mathrm{O}_{2} \longrightarrow 6 \mathrm{CO}_{2}+6 \mathrm{H}_{2} \mathrm{O}+
$$

For every $1.0 \mathrm{mg}$ of glucose metabolised, $1.067 \mathrm{mg}$ of $\mathrm{O}_{2}$ is taken up and $1.467 \mathrm{mg}$ of $\mathrm{CO}_{2}, 0.60 \mathrm{mg}$ of $\mathrm{H}_{2} \mathrm{O}$, and $15.6 \mathrm{~kJ}$ of heat are produced. Thus, even if a very efficient heat transfer mechanism exists so that all the respiration heat energy is properly dissipated and the $\mathrm{RH}$ is $100 \%$, so there is no mass transfer driving force transporting water from the produce, the carbon loss resulting from the production of $\mathrm{CO}_{2}$ will still lead to a weight loss of $0.40 \mathrm{mg} / \mathrm{mg}$ of glucose metabolised. This inherent transpiration rate (Rinh) can be calculated since the $\mathrm{O}_{2}$ uptake rates are known for the four produce examined. For example, the steady-state respiration rate for mushrooms in air at optimum temperature was determined to be $12 \mathrm{ml} \mathrm{O}_{2} / \mathrm{kg} / \mathrm{h}$ (Figure 1) or $16.8 \mathrm{mg} \mathrm{O} / \mathrm{kg} / \mathrm{h}$. This $\mathrm{O}_{2}$ uptake rate would translate to a glucose metabolic rate of $15.7 \mathrm{mg} / \mathrm{kg} / \mathrm{h}$, and $\mathrm{CO}_{2}, \mathrm{H}_{2} \mathrm{O}$, and enthalpy production rates of $23.0 \mathrm{mg} / \mathrm{kg} / \mathrm{h}$, $9.6 \mathrm{mg} / \mathrm{kg} / \mathrm{h}$ and $245 \mathrm{~kJ} / \mathrm{kg} / \mathrm{h}$, respectively. Consequently, the inherent mushroom transpiration rate would be $6.1 \mathrm{mg} / \mathrm{kg} / \mathrm{h}$. By similar calculations, the Rinh for strawberry, broccoli and tomato were $5.1,5.6$, and $1.8 \mathrm{mg} / \mathrm{kg} / \mathrm{h}$, respectively. The results of Figure 5 indicate that, even at $100 \% \mathrm{RH}$ (i.e. DVP $=0$ ), transpiration losses much higher than the inherent transpiration rate were observed for all four produce.

For tomatoes, Rinh could account for $40 \%$ of the zero DVP weight loss whereas with mushrooms, it was only $10 \%$. These discrepancies must therefore result from the inefficient removal of heat from the storage containers (Lentz and Rooke, 1964 ; Burg and Kosson, 1983). Heat is produced in containers at a rate of 245, 204, 225 and $71.5 \mathrm{~kJ} / \mathrm{kg} / \mathrm{h}$ for mushrooms, strawberries, broccoli and tomatoes, respectively. If the enthalpy of vaporization of water is taken as $2,480 \mathrm{~kJ} / \mathrm{kg}$, for mushroom this would be enough heat to vaporize $98.0 \mathrm{~g} \mathrm{H}_{2} \mathrm{O} / \mathrm{kg} / \mathrm{h}$. Obviously, this heat must be very efficient removed if moisture loss it to be avoided.

Even with gas flowing through the container, heat did tend to accumulate in the system, leading to elevated temperatures at the center of the package. We observed that the core temperature was often 2 to $4^{\circ} \mathrm{C}$ higher than the wall temperature. Thus, even if the gas was at
$100 \% \mathrm{RH}$ as it entered the package, an increase in temperature would lead to a decrease in $\mathrm{RH}$ at the center of the container. As a result, a mass transfer driving force would be created that would lead to water transport from the produce to the surrounding atmosphere (Ben-Yehoshua, 1987; Grierson, 1975). This rate of water loss at $100 \% \mathrm{RH}$ can be defined as the heat-transferinduced transpiration rate (Rhti) and had values of $54.0,27.8,19.7$ and $3.0 \mathrm{mg} / \mathrm{kg} / \mathrm{h}$ for mushrooms, strawberries, broccoli and tomatoes, respectively. There does not appear to be a direct correlation between the Rhti values and the rate of heat production for the four produce examined. Other factors, such as packaging density, transport surface area and permeability of the produce skin surface most likely also play a role in determining the value of Rhti. The results showed that mushrooms and strawberries are more sensitive to water stress than broccoli or tomatoes. This may be explained by the porous structure of mushrooms and the permeability of the tissues of strawberries. Broccoli is more resistant than either of these but less resistant than tomatoes, which possess a waxy envelope making them much more impermeable. The resistance of broccoli may also be attributed to the stem.

When the surrounding atmosphere has an $\mathrm{RH}$ of $100 \%$ and is the desired storage temperature, then only the produce in the temperature elevated core will experience water loss. However, if the $\mathrm{RH}$ of the gas at the optimal storage temperature drops below $100 \%$, an additional mass-transfer-induced transpiration (Rmti) will occur for all produce in the container. This increase in transpiration with increasing DVP was observed for all produce examined (Figure 5). According to Fick's first law, the rate of masstransfer-induced transpiration should be directly proportional to the concentration driving force (DVP).

However, plots of transpiration versus DVP (Figure 5) are not straight and tend to curve upwards as DVP increases. This curvature most likely results because heat-transfer-induced and mass-transfer-induced transpiration are not independent phenomena. A higher rate of mass transfer will produce more evaporative cooling at the surface of the produce. This in turn will reduce the core temperature and decrease Rhti. Consequently, at low DVP values, the two phenomena tend to be antagonistic. However, at higher DVP values, mass-transfer-induced transpiration would be the dominant weight loss mechanism and the curve becomes linear. 


\section{CONCLUSION}

This study has provided an evaluation of certain environmental factors (atmosphere, temperature, relative humidity) on the physiological behaviour (respiration and transpiration) of fresh fruits and vegetables. Knowledge of these behaviours will provide means of devising better storage methods for a given product. The data have allowed the identification of elements relevant to the design of packages for modified atmosphere packaging and for the modelization of modified atmosphere packaging. Knowledge of the respiratory quotient under different atmospheric conditions and as a function of storage temperature provides information about the substrate being metabolized by a given product. Similarly, measurement of transpiration as a function of relative humidity provides means of determining the critical relative humidity below which significant amounts of water may be lost from the product. The method based on measurement of transpiration seems reliable when data already in the literature are considered. This work has in addition demonstrated that transpiration by fruits and vegetables depends on the difference in vapour pressure between the product and the surrounding package atmosphere, on respiration in the product (inherent respiration) and on intrinsic factors associated with each product.

\section{REFERENCES}

Bastrash (S.) ; (J.) Malhlouf ; (F.) Cataigne and (C.) Villemot. 1993. Optimal controlled Atmosphere conditions for storage of broccoli florets. J. Food Sci. 58(2) : 338-341.

Ben-Yehoshua (S.) ; (S. P.) Burg and (R.)Young. 1985. Resistance of citrus fruits to mass Transport of water vapour and other gases. Plant physiol. 79 : 1084 - 1053

Ben-Yehoshua (S.). 1987. Transpiration, water stress, and gas exchange in Postharvest Physiology of vegetables. (J.) Weichman ed. Marcel Dekker, New York, NY, pp.113.

Bhowmik (S. R.) and (J. C.) Pan. 1992. Shelf life of Mature Green Tomatoes Stored in Controlled Atmosphere and High Humidity J. Food Sci. 57(4) : 948-953.

Bolhing $\left(\mathrm{H}_{\text {. }}\right)$ and $(\mathrm{V}$.$) Hassen. 1980. Influence of$ controlled atmospheres ont the respiration Activity of a chlorophyllous post-harvest mushroom quality. Biotech. Letters 9(8) : 529-534.
Burg (S. P.) and (R. M.) Kosson. 1983. Metabolim, heat transfert and water lossunder hydrobaric conditions. In post harvest physiology and crop preservation. (M.) Lieberman ed., Plenum "ress, New York. Pp.399.

Burton (K. S.) ; (C. E.) Frost and (R.) Nichols. 1987. A combinaison of plastic permeable films system for controlling post harvest mushroom quality. Biotech. Letters. 9(8) : 529-534.

Cameron (A. C.) ; (R. M.) Beaudry ; (N. H.) Banks and (M. V.) Yelanich. 1994. Modified Atmosphere packaging of blueberry fruit : Modelling respiration and package oxygen partial pressures as a function of temperature. J Amer. Hort. Sci. 119(3) : 546-550.

Church (J. I.) and (A. L.) Parson. 1995. Modified Atmosphere Packaging technology : A Review. J. Sci. Food Agric. 67 : 143-152.

Doyon (G.). 1989. Conservation des fruits sous micro - environnements : Caractérisation de l'activité métabolique des fraises fraîches et entreposées sous atmosphères modifiées. Presse de l'Université Laval, Québec. 186p.

Exama (A.) ; (J.) Arul ; (R. W.) Lencki ; (L. Z.) Lee and (C.) Toupin.1993. Suitability of plastic Films for modified atmosphere packaging of fruits and vegetables. J. Food Sci. 58 : $1365-1370$

Grierson (W.) and (W. F.) Wardowski. 1975. Humidity in horticulture. Hort. Sc. 10(4) : 356-360.

Grierson (W.) and (W. F.) Wardowski. 1978. Relative Humidity effets on the postharvest life of fuits and vegetables. Hort. Sc. 13(5) : 570-574.

Harris (C. M.) and (J. M.) Harvey. 1973. Quality and decay of california strawberries stored in $\mathrm{CO}_{2}$-enriched atmosphères. Plant Dis. Rep. $57: 44-46$.

Kader (A. A.) ; (D.) Zagory and (E. L.) Kerbel. 1989. Modified atmosphere packaging of fruits and vegetables. CRC Rev. Food Sci. Nutr. 28(1) : 1-30.

Kader (A. A.). 1986. Biochemical and physiological basis for effects of controlled and modified atmospheres on fruits and vegetables. Food Technology . 40(5) : 99-104.

Kader (A. A.). 1987. Respiration and gas exchanges of vegetables. In Postharvest physiology of vegetables. (J.) Weichman (ed) Marcel Dekker, New York, NY, pp 25.

Kato-Noguchi (H.) and (A. E.) Watada.1996. Regulation of glycolytic metabolism in fresh 
cut carrorts under low oxygen atmosphere. J. Amer. Soc. Hort Sci.121(1) : 123-126.

Lentz (C. P.) and (E. A.) Rooke. 1964. Moisture loss of apples under refrigeration storage conditions. Food Technology. 18 : 119-124.

Lockhart (C. L.) and (C. A.) Eaves. 1967. The influence of low oxygen levels and relative humidity on storage of green tomatoes. Hort Sci. : 42 : 289-294.

Murr ( D. P.) and (L. L.) Morris. 1975a. Effect of storage temperature on postharvest changes in mushrooms. J. Amer. Hort. Sci. 100(1) : $16-19$.

Murr (D. P.) and (L. L.) Morris. 1975b. Effect of storage atmosphere on postharvest growth of mushrooms. J Amer. Hort. Sci. 100(3) : 298-301.

Nichols (R.) and (J. B. W.) Hammond. 1975. The relationship between respiration atmosphere and quality in intact and perforated mushroom packs J. Food Technol. $10:$ 427-435.

Patel ( P. N.) ; (T. K.) Pai and (S. K.) Sastry. 1988. Effects of temperature relative humidity and storage time on the transpiration coefficients of selected perishables. Trans. ASHRAE 94 : 1563-1587.
Phan (C. T.). 1987. Temperature effect on metabolism in Postharvest physiology of vegetables. (J.) Weichman ed. Marcel Dekker New York NY. pp 173-180.

Robinson (J. E.) ; (K. M) Browne and (W. G.) Burton. 1975. Storage characteristics of some vegetables and soft fruits. Ann. Appl. Biol. 81-399.

Salunke (D. K.) and (M. T.) Wu. 1973. Effects of low oxygen atmosphere storage on repenning and associated biochemical changes of tomato fruits. J. AMER. Soc. Hort. Sci. 98(1) : 12-14.

Sastry (S. K.) ; (C. D.) Baird and (D. E.) Buffington. 1978. Transpiration rates of certain fruits and vegetables. ASHRAE Trans. 84 -237.

Smith (R. B.). 1992. Controlled atmosphere storage of «Redcoat» straberry fruit. J. Amer. Soc. Hort. Sci. 117 : 260-264.

Sveine (E.) ; (A.) Klougart and (C. R.) Rasmassin. 1967. Ways of prologing the shelf-life of fresh mushrooms. Mushrooms Sci. 6 : 463-464.

Xu (H.) ; (L.) Gauthier and (A.) Gosselin. 1995. Stomatal and cuticular transpiration of greenhouse tomato plants in response to high solution electrical conductivity and low soil water content. J. AMER. Soc. Hort. Sci. 120 : 417-422. 